Research Article

\title{
Improvement of Cochineal Extract (Dactylopius coccus Costa) Properties Based on the Green Synthesis of Silver Nanoparticles for Application in Organic Devices
}

\author{
Carina Stael, Ricardo Cruz, Blanca Naranjo, Alexis Debut $\mathbb{D}$, and Yolanda Angulo \\ Centro de Nanociencia y Nanotecnología, Universidad de las Fuerzas Armadas ESPE, Av. Gral. Rumiñahui S/N, \\ P.O. Box 171-5-231B, Sangolquí, Ecuador \\ Correspondence should be addressed to Yolanda Angulo; yrangulo@espe.edu.ec
}

Received 18 October 2017; Revised 11 January 2018; Accepted 7 February 2018; Published 21 May 2018

Academic Editor: Lee Blaney

Copyright (c) 2018 Carina Stael et al. This is an open access article distributed under the Creative Commons Attribution License, which permits unrestricted use, distribution, and reproduction in any medium, provided the original work is properly cited.

The UV-Vis absorption and conductivity properties of the organic sample cochineal (Dactylopius coccus Costa) were modified by using it as a reducing agent in the biosynthesis of silver nanoparticles. This was done in a straightforward way in order to allow its possible application in organic devices. The biosynthesized solution exhibited a hybrid material with a UV-Vis absorbance range from 205 to $650 \mathrm{~nm}$. The sizes of silver nanoparticles of the hybrid material were between 5 and $10 \mathrm{~nm}$. X-ray diffraction (XRD) revealed silver structures, when samples were dried at $100^{\circ} \mathrm{C}$. At $40^{\circ} \mathrm{C}$, the structures detected were chlorargyrite $(\mathrm{AgCl})$ and silver oxide $\left(\mathrm{Ag}_{2} \mathrm{O}\right)$. The nucleation and subsequent growth of the hybrid thin film on the substrates indicated an increase of clusters and roughness in comparison to thin films made solely from cochineal. The thin films of hybrid materials showed an improvement of $40 \%$ in their electrical potential. The stability at room temperature demonstrated that the hybrid material could be useful as a potential candidate for photoactive thin films in organic devices.

\section{Introduction}

Organic semiconductors have witnessed considerable development in recent years, with increasing research activity on this class of materials and their potential applications. The interest in this area is to obtain new organic compounds with improved, more efficient properties for the manufacture of organic, light-emitting diodes (OLEDs) [1], organic photovoltaic cells (OPVs) [2, 3], and thin film transistors (TFTs) [4]. The biosynthesis of new hybrid structures using natural organic compounds for development of photoreactive compounds is straightforward and significantly reduces the cost of organic devices.

Cochineal insects (Dactylopius coccus C.) from the city of Loja, Ecuador, were used here to form a new hybrid structure. Cochineal is not only the main red dye used in Central America, but it was also used in Ecuador and Peru by the Incas, before the Spanish conquest. Cochineal is made up of $80 \%$ carminic acid (CA). In the 16th century, it was exported to Europe and began to replace the domestic kermes insect
(Kermes vermilio) [5, 6]. Cochineal insects are nowadays widely used in the food industry to replace synthetic colorants, and its antioxidant properties have been well known for a long time $[7,8]$.

In this study, we observed the increased UV-Vis spectral absorbance and electrical conductivity of the natural pigment through biosynthetic silver nanoparticles [5]. To improve the optical and electrical properties of cochineal, it was used as the reducing agent during the biosynthesis of silver nanoparticles (AgNPs) without submitting the cochineal to any kind of separation of its primary compounds. The cochineal extract was used as the reducing agent for the biosynthesis of AgNPs, since green synthesis of the AgNPs has been an easy, affordable, inexpensive technique and is potentially not harmful to human health and the environment [9-14]. Different volumes of cochineal dye $(\mathrm{pH}=12,[5])$ in $1 \mathrm{ml}$ of $\mathrm{AgNO}_{3}$ solution $(10 \mathrm{mM}$, $\mathrm{pH}=5.6)$ were analyzed with UV-Vis spectrometry, Commission Internationale de l'Eclairage (CIE) chromaticity diagram, cyclic voltammetry $(\mathrm{CV})$, scanning transmission electron microscopy (STEM), energy dispersive X-ray spectroscopy 
(EDS), dynamic light scattering (DLS), and X-ray diffraction (XRD). The surface morphology and electrical properties of the thin films were analyzed using atomic force microscopy (AFM). This suite of analytical tools facilitated the study of the thin films from multiple perspectives and explained their increased conductivity properties.

\section{Materials and Methods}

2.1. Materials. Dactylopius coccus Costa samples were obtained from the city of Loja, Ecuador. The insects, which were found in the tuna (fruit) of Opuntia ficus-indica, secrete a white and cottony substance that serves to protect them from external, environmental conditions. The interesting property of these insects is that they generate a natural red pigment inside their body. The goal of this research was to improve the properties of the cochineal by the synthesis of silver nanoparticles. The silver nitrate and all the solvents used in the sample preparation were obtained from Sigma-Aldrich (Missouri, United States).

2.2. Hybrid Material Synthesis. Ten grams ( $10.0 \mathrm{~g}$ ) of the cochineal sample was dissolved in $3.0 \mathrm{~L}$ of methanol and distilled water (9:1, resp.). This solution was evaporated using a Rotavapor (Buchi R-220) at $40^{\circ} \mathrm{C}$ and a pressure of $44000 \mathrm{~Pa}$ before being vacuum-filtered (a filter paper of $0.45 \mu \mathrm{m}$ ). For the reduction of $\mathrm{AgNO}_{3}$, the pigment was diluted with $\mathrm{NaOH}$ to obtain a $\mathrm{pH}$ of 12 [9]. For the biosynthesis of AgNPs, different volumes $(0.1 \mathrm{ml}$ and $0.4 \mathrm{ml})$ of the alkaline solution (cochineal at $\mathrm{pH}$ 12) were diluted with $1 \mathrm{ml}$ of $\mathrm{AgNO}_{3}$ solution $(10 \mathrm{mM}$; $\mathrm{pH}=5.6$ ), and this mixture was incubated for $1 \mathrm{~h}$ at $40^{\circ} \mathrm{C}$.

\subsection{Physical and Chemical Characterization of the Hybrid} Material. The stability of the nanoparticles in solution at room temperature was measured after 8 days using UV-Vis spectrometry (Analytik Jena S600). CIE chromaticity diagram was analyzed using OSRAM Sylvania, Inc. (2009) software. Cyclic voltammetry was done using a three-electrode system (Metrohm Autolab PGSTAT 128N). The working electrode was a carbon electrode; a calomel $(\mathrm{Hg} / \mathrm{HgCl})$ electrode was used as reference and a platinum strand served as the auxiliary electrode. The analyses were conducted in a background electrolyte solution of $0.1 \mathrm{M} \mathrm{KCl}$. Prior to each analysis, dissolved oxygen in the $\mathrm{KCl}$ solution was removed by bubbling with $\mathrm{N}_{2}$ (g) for $15 \mathrm{~min}$. The voltammetry scan rate was $0.05 \mathrm{~V} \cdot \mathrm{s}^{-1}$ at room temperature in the range from -1.2 to $1.2 \mathrm{~V}$ of the standard hydrogen electrode versus saturated calomel electrode (SHE versus SCE).

Particle size and morphology of the samples were analyzed by a scanning transmission electron microscope (TESCAN MIRA3) operating at an accelerating voltage of $25 \mathrm{kV}$ equipped with a Bruker EDS XFlash 6130 detector. Dynamic light scattering (Horiba LB-550) was used to determine the hydrodynamic diameter of the AgNPs. All DLS measurements were performed at a $25^{\circ} \mathrm{C}$ fixed temperature.

Organic layers were grown onto quartz, silicon, and indium tin oxide (ITO)/glass substrates for the optical spectroscopy and morphology study of the samples' thin films. Before spin coating $\left(40^{\circ} \mathrm{C}\right)$ the thin films, the substrates were cleaned with detergent, rinsed with deionized water, sonicated in organic solvents and acetone, and rinsed with alcohol before being dried in a $\mathrm{N}_{2}(\mathrm{~g})$ stream. X-ray patterns of the thin films from different samples were collected on an Empyrean diffractometer (PANalytical) in the Bragg-Brentano configuration at $40 \mathrm{kV}$ and $45 \mathrm{~A}$ with monochromatic $\mathrm{X}$-rays of Cu K-alpha wavelength $(\lambda=1.541 \AA)$. The morphology in the ScanAsyst mode and surface conductivity in the conductive atomic force microscopy mode of the thin films were studied with a Bruker Icon atomic force microscope.

\section{Results and Discussion}

3.1. Hybrid Material Characterization. The UV-Vis absorption spectra of the cochineal solutions were obtained at $\mathrm{pH} 3.8$ and 12.0 (Figure 1(a)). This $\mathrm{pH}$ change improves the cochineal reducing properties, which are conducive for the formation of AgNPs. Both solutions were stable at room temperature throughout the analysis. The inset in Figure 1(a) shows the corresponding CIE chromaticity diagram. The chromaticity of the solutions changed as a function of $\mathrm{pH}$ (inset in Figure 1(a); $\mathrm{pH}$ 3.2: $x=0.318, y=0.346 ; \mathrm{pH} 12.0: x=0.304, y=0.372$ ). Gaussian fitting of the curves (Figure 1(b), $\mathrm{pH} 3.2: \chi^{2}=0.14$; Figure $\left.1(\mathrm{c}), \mathrm{pH} 12: \chi^{2}=0.04\right)$ shows a red shift in their wavelengths and a decrease in their half width at half maximum (HWHM). These changes are due to the predominance of carminic acid in cochineal, which has an anthraquinone nucleus. When diluted in distilled water $(\mathrm{pH}=3.8)$ or in methanol $(\mathrm{pH}=12)$, maximum absorption peaks can be observed in three bands: $243 \sim 243.5 \mathrm{~nm}, 280 \sim 282 \mathrm{~nm}$, and $324 \sim 331 \mathrm{~nm}$, respectively, with a slight bathochromic shift, but with a strong hypsochromic shift at a wavelength from $383.6 \mathrm{~nm}$ to $302.5 \mathrm{~nm}$. This effect is caused not only by the carboxyl group in the C2 position but also by the deprotonation of hydroxyls in positions $\mathrm{C} 3, \mathrm{C} 5, \mathrm{C} 6$, and $\mathrm{C} 8$, which are stable at $\mathrm{pH} 12$ and responsible for the hydroxyanthraquinone chromophore properties. The red color of the molecule is explained by the degree of oxidation of the anthraquinone nucleus with the maximum absorbance at $496 \mathrm{~nm}$ [15-17], similar to the one found in the analyzed extract.

Figures 2(a) and 2(b) show absorption spectra of the biosynthesis of silver nanoparticles (AgNPs) from the cochineal extract, and the difference of the two spectra is the volume of cochineal. Insets in Figures 2(a) and 2(b) show the time-dependent stability of AgNPs (Figure 2(a): $\lambda=443 \mathrm{~nm}$; Figure 2(b): $\lambda=428.5 \mathrm{~nm}$ ). From Figure 2(a), one can observe that the sample prepared with $0.1 \mathrm{ml}$ of the cochineal extract in $1 \mathrm{ml}$ of silver nitrate reached stability at $72 \mathrm{~h}$. On the contrary, Figure 2(b) shows faster kinetics for the biosynthesis of AgNPs from $0.4 \mathrm{ml}$ of the cochineal extracts in $1 \mathrm{ml}$ of silver nitrate, reaching stability around $24 \mathrm{~h}$. The faster reaction kinetics of the last sample $(0.4 \mathrm{ml}$ of the cochineal extract in $1 \mathrm{ml}$ of $\mathrm{AgNO}_{3}$ ) likely stems from the fourfold increase in the reducing agent volume.

Figure 3(a) shows the UV-Vis spectra of the cochineal extract at $\mathrm{pH} 12.0$ and after the biosynthesis of AgNPs on the eighth day. The inset in Figure 3(a) shows the CIE chromaticity diagram for the extracts at $\mathrm{pH} 12(x=0.251$, $y=0.406)$ and the biosynthesis of AgNPs with $0.1 \mathrm{ml}$ $(x=0.255, y=0.238)$ and $0.4 \mathrm{ml}(x=0.275, y=0.315)$ of the cochineal extract. The results show that the biosynthesis of 


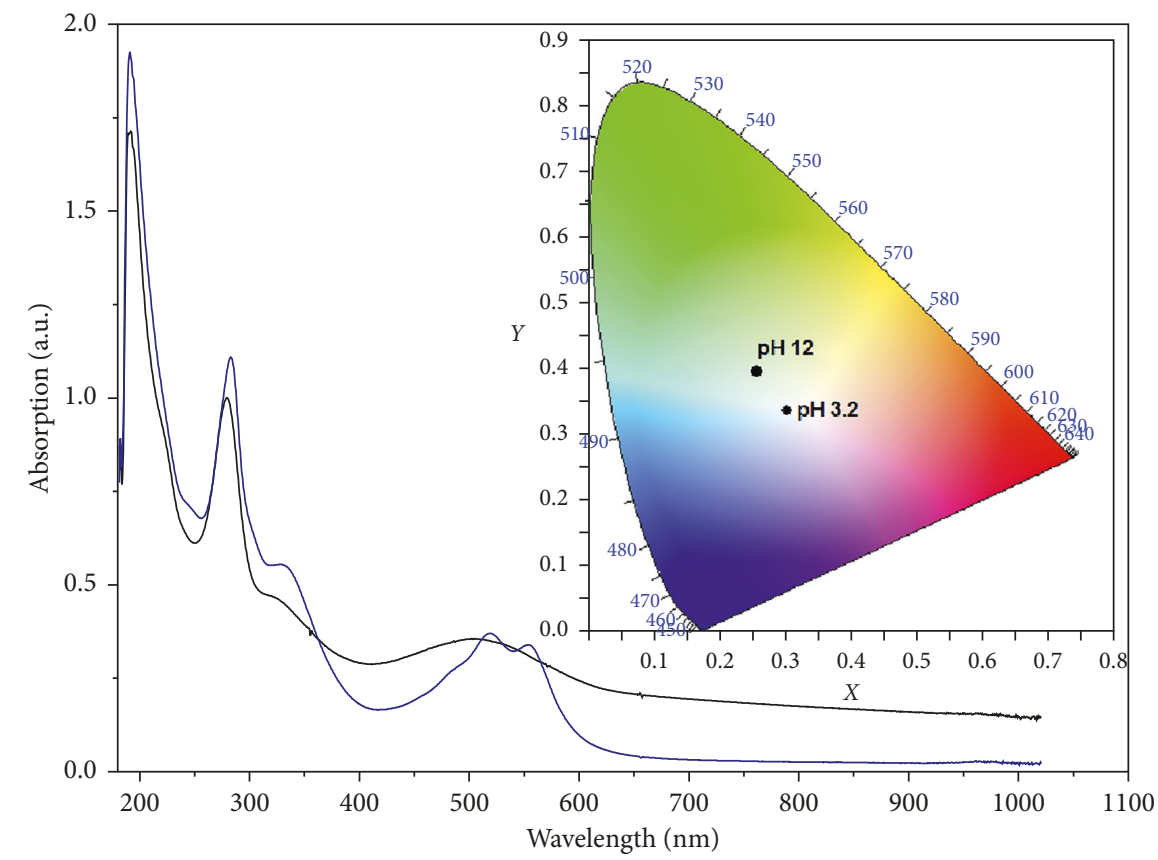

(a)

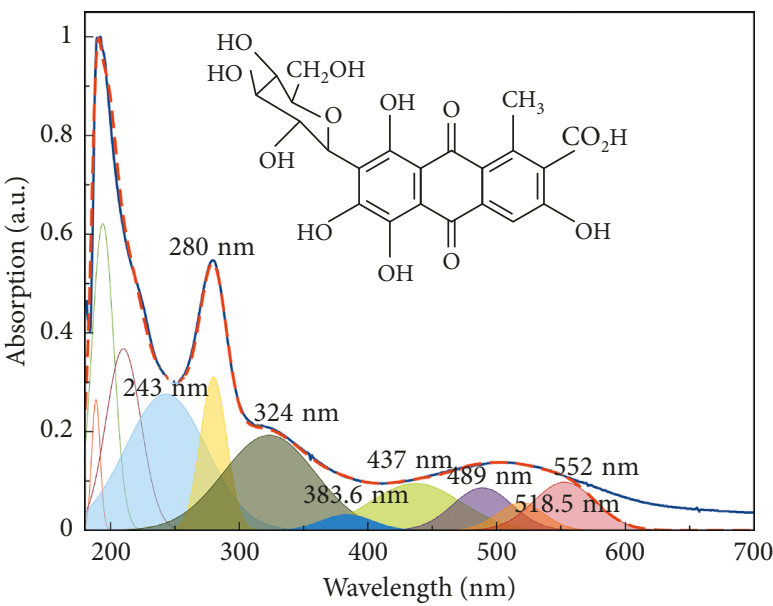

(b)

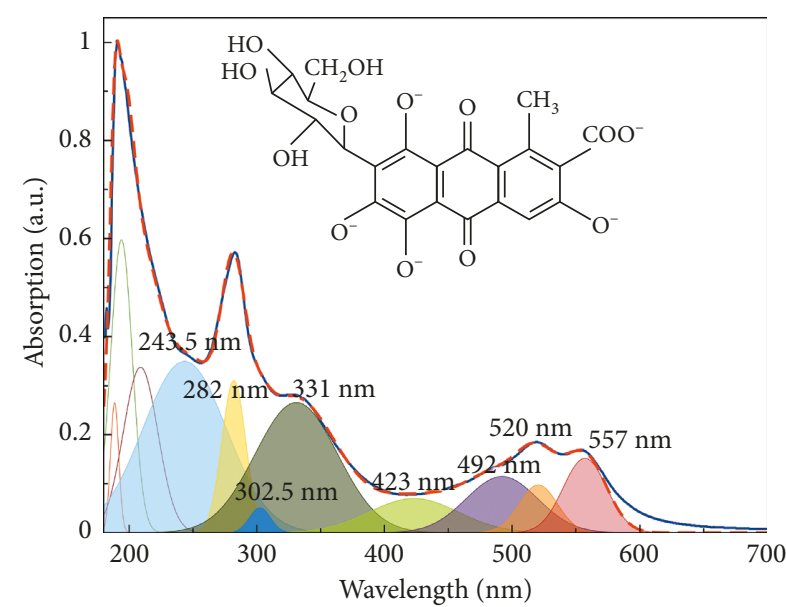

(c)

Figure 1: (a) UV-Vis spectra of cochineal pigment at pH 3.8 (black) and 12.0 (blue) with corresponding CIE chromaticity diagram (inset). Linear least-squares models (red dashed lines) of Gaussian components of cochineal pigment spectra (solid blue lines) at pH 3.8 (b) and 12.0 (c). Insets in (b) and (c) show the chemical structures of cochineal pigment at $\mathrm{pH} 3.8$ and $\mathrm{pH} 12.0$.

AgNPs with $0.4 \mathrm{ml}$ of the cochineal extract has greater spectral absorbance in the UV-Vis region, indicating a possible candidate for photoactive thin films of organic solar cells [18-21].

According to Mie's theory, optical properties of metal nanoparticles are dominated by localized surface plasmon resonance (LSPR), and the profile of LSPR bands depends on the shape of the particle $[21,22]$. The AgNP mixture with $0.4 \mathrm{ml}$ of the cochineal extract presented a single surface plasmon absorption band at $428.5 \mathrm{~nm}$ (Figure 3(c) and Table 1); however, the AgNP mixture with $0.1 \mathrm{ml}$ of the cochineal extract presented two plasmon bands at $443 \mathrm{~nm}$ with a weak shoulder peak at $379 \mathrm{~nm}$ (Figure 3(b) and Table 1), possibly suggesting nonspherical (irregularly shaped) particles [22, 23]. Hence, the two plasmon bands (at $379 \mathrm{~nm}$ and $433 \mathrm{~nm}$; Table 1) presented by the Gaussian fit shown in Figure 3(b) $(0.1 \mathrm{ml}$ of the cochineal extract) imply the nonspherical nanoparticles [21, 22-24]. The nanoparticles formed with $0.4 \mathrm{ml}$ of the cochineal extract are more likely being spherical in shape because only one band was observed at $428.5 \mathrm{~nm}$ (Figure 3(c) and Table 1). As the number of plasmon bands observed is indicative of the shape of the nanoparticles, those nanoparticles formed in the presence of $0.4 \mathrm{ml}$ of the cochineal extract had a higher probability of being spherical in shape [21]. 


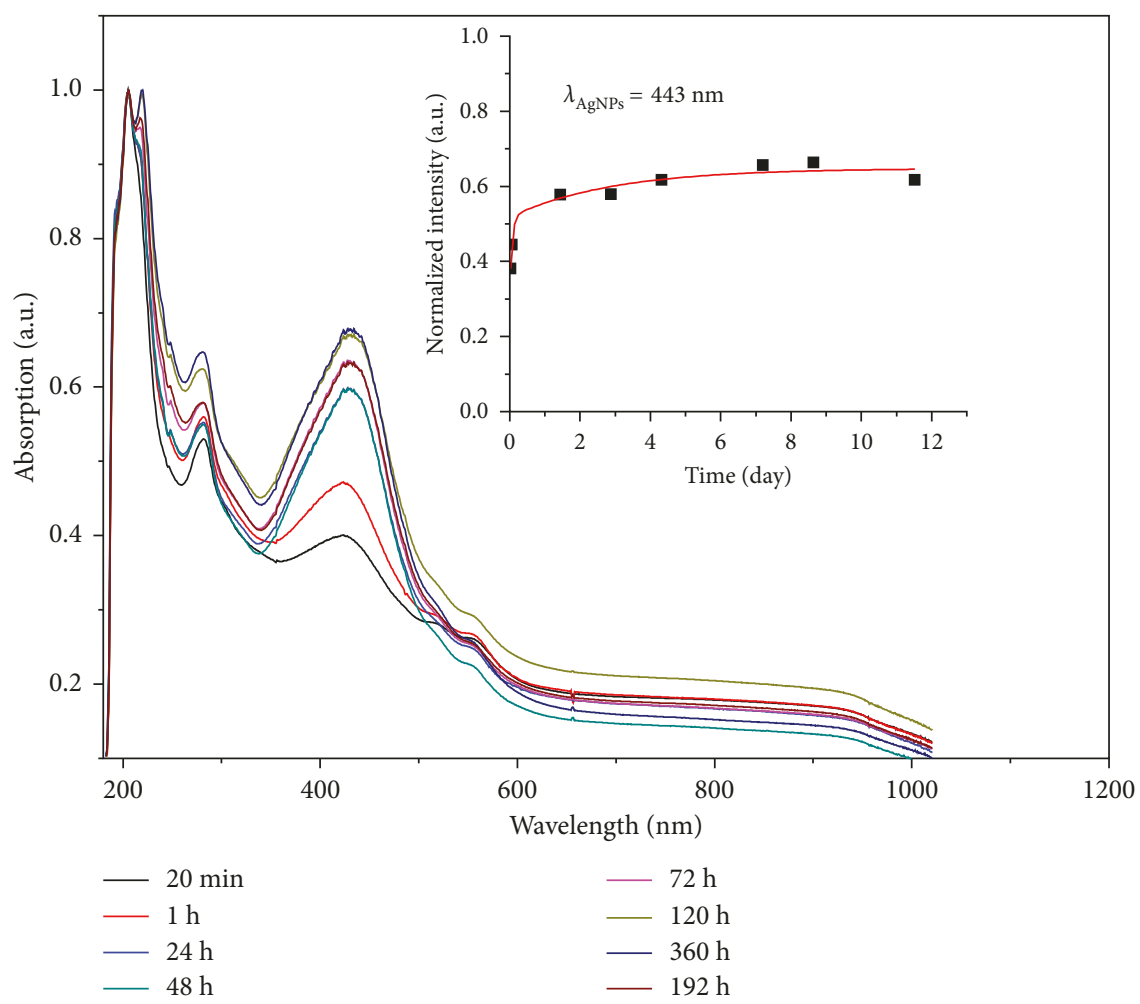

(a)

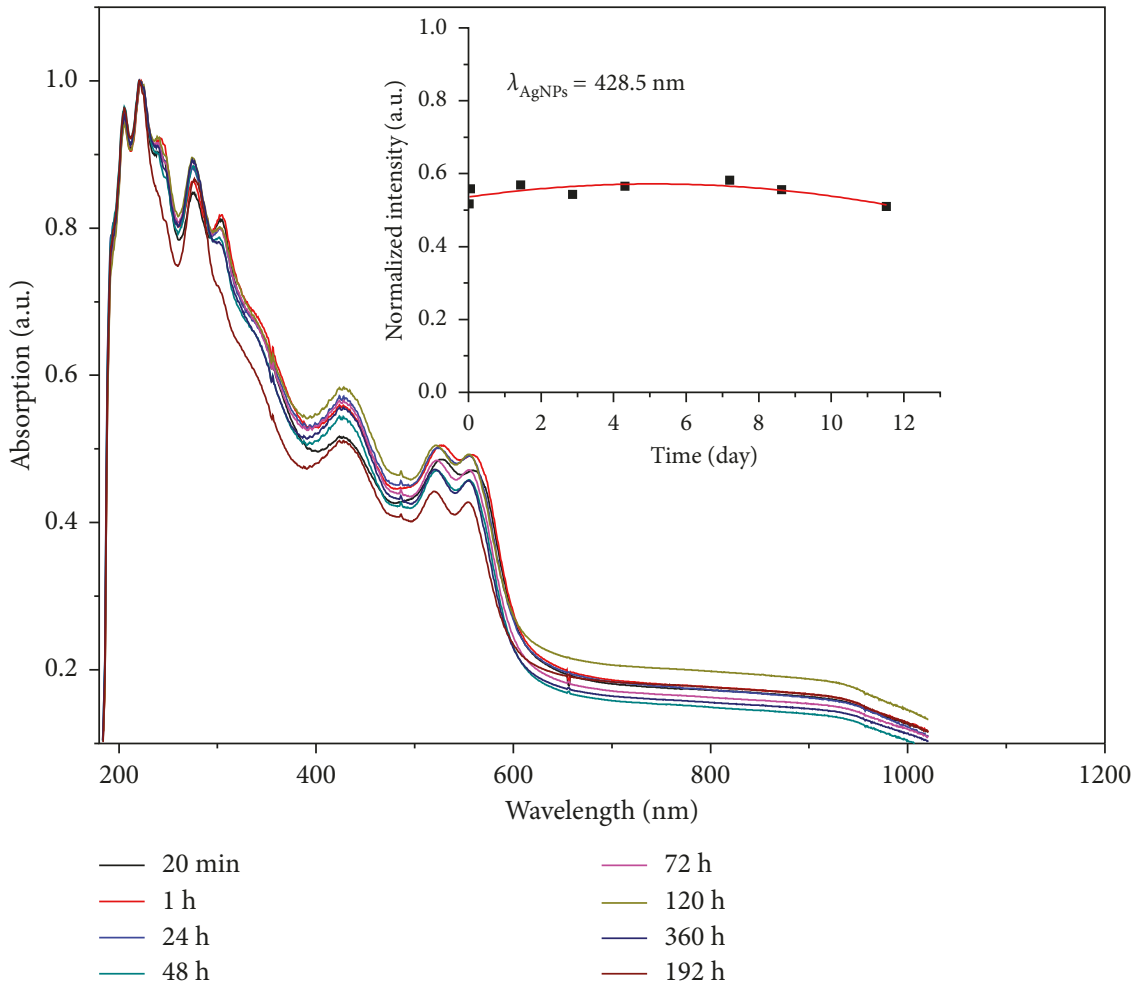

(b)

Figure 2: UV-Vis spectra collected over time during the formation of AgNPs in (a) $0.1 \mathrm{ml}$ and (b) $0.4 \mathrm{ml}$ of cochineal pigment solution. Insets follow the intensity of the absorbance peak over time $(0.1 \mathrm{ml}$ of cochineal extract: $443 \mathrm{~nm}$ and $0.4 \mathrm{ml}$ cochineal extract: $428.5 \mathrm{~nm}$ ). 


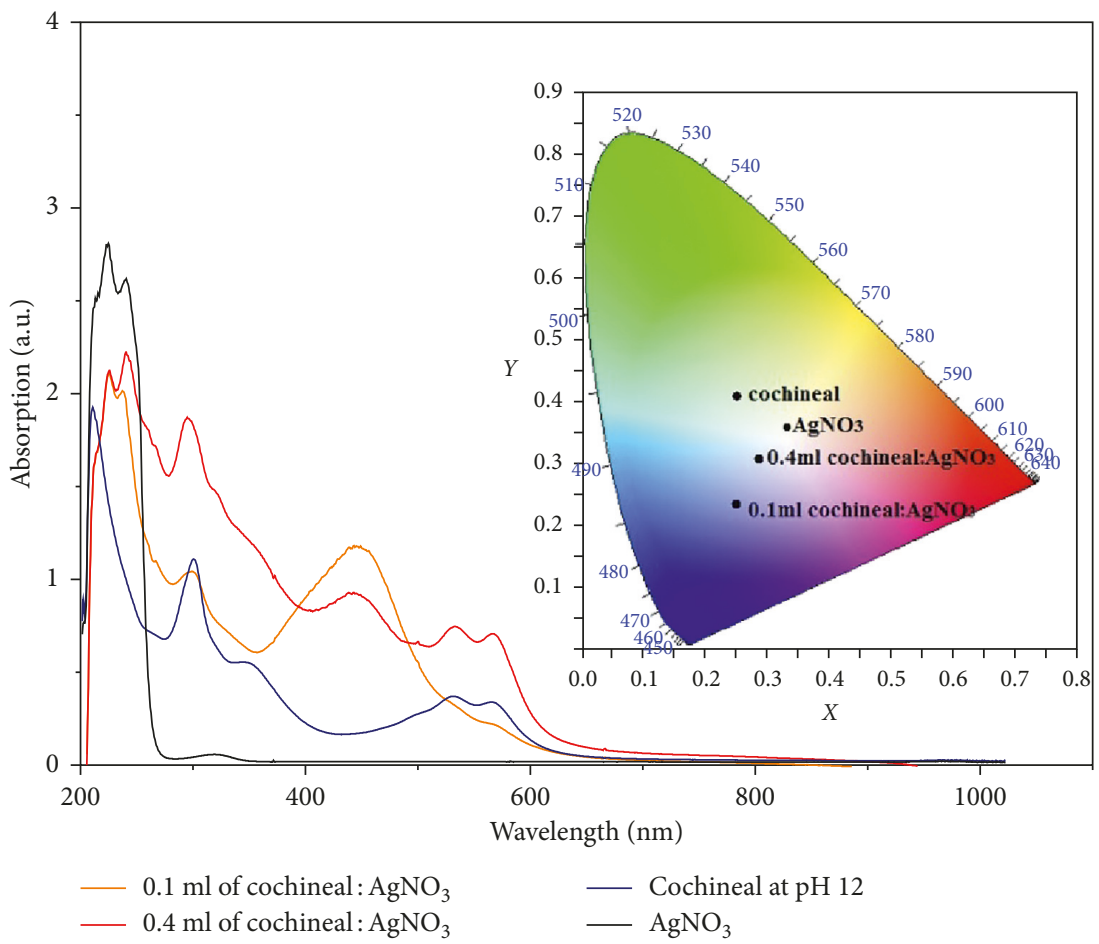

(a)

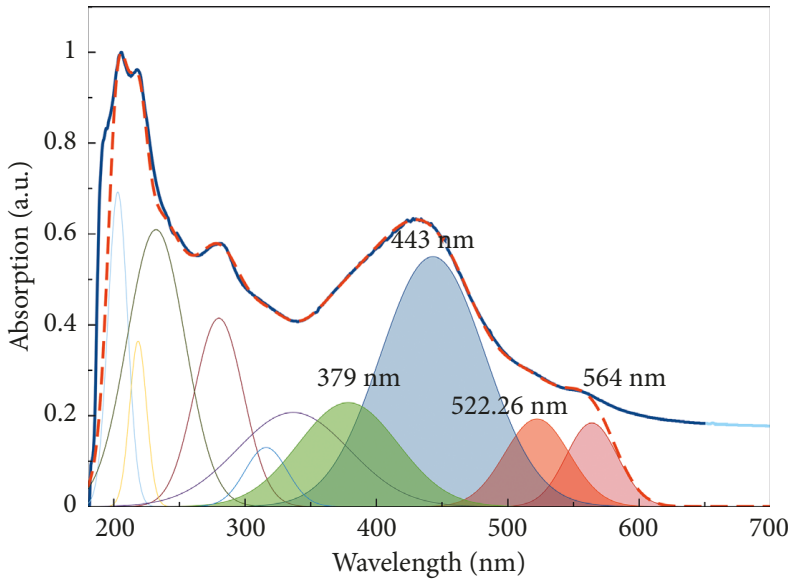

(b)

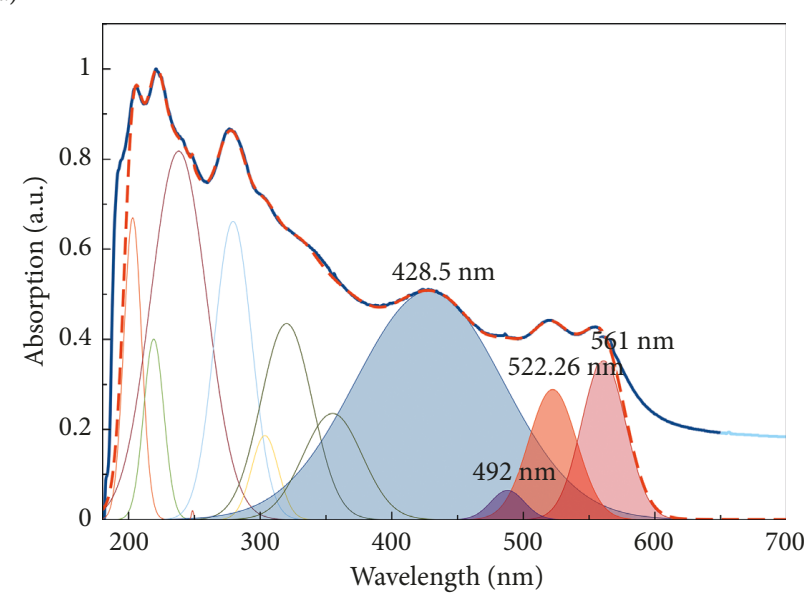

(c)

Figure 3: (a) Comparison of UV-Vis spectra of cochineal pigment ( $\mathrm{pH} 12.0$ ), silver nitrate, and AgNPs synthesized from (b) $0.1 \mathrm{ml}$ and (c) $0.4 \mathrm{ml}$ of the cochineal extract. The inset in (a) shows the corresponding CIE chromaticity diagram: cochineal pigment ( $\mathrm{pH} 12.0$, $x=0.251, y=0.406)$, AgNPs $(0.1 \mathrm{ml}$ of the cochineal extract, $x=0.255, y=0.238)$, and AgNPs $(0.4 \mathrm{ml}$ of the cochineal extract, $x=0.275$, $y=0.315$ ). Linear least-squares models (dashed red lines) of UV-Vis spectra (solid blue lines) with Gaussian components are shown in (b) AgNPs (0.1 ml of the cochineal extract) and (c) AgNPs ( $0.4 \mathrm{ml}$ of the cochineal extract).

\subsection{Physical and Chemical Characterization of the Hybrid} Material. The spherical AgNPs were also indicated by a STEM image in the sample synthesized from $0.4 \mathrm{ml}$ of the cochineal extract (Figure 4(b)) in agreement with the suggested results obtained of the LSPR bands. In the other sample, Figure 4(a) shows a diffuse image with very small particle sizes and, therefore, inconclusive results about the true morphology of the particles. EDS (Figure 4(c)) analysis confirmed that the particles were composed of silver when synthesized from cochineal solutions. The weight percentage of $\mathrm{Ag}$ in each sample $(0.1 \mathrm{ml}$ and $0.4 \mathrm{ml}$ of the cochineal extract) was similar because the volume of silver nitrate in the reagent was the same (Table 2). The size distribution of the different AgNPs ranged between 5 and $15 \mathrm{~nm}$ using DLS (Figure 4(d)).

The X-ray pattern was recorded from the same batch of samples (Figure 5). The inset in Figure 5 shows ApNPs synthesis with $0.4 \mathrm{~mL}$ of the cochineal extract, which was dried at $100^{\circ} \mathrm{C}$ as well as a graphical representation of the scattering of $\mathrm{X}$-rays in the film. When the thin film was dried at $40^{\circ} \mathrm{C}$, chlorargyrite $(\mathrm{AgCl})$, silver oxide $\left(\mathrm{Ag}_{2} \mathrm{O}\right)$, and other structures were observed (Table 3 ). The reason is that the 
TABLE 1: Wavelength analysis of the half width at half maximum (HWHM) of cochineal at pH 12 and biosynthetic AgNPs at different initial volumes $(0.1$ and $0.4 \mathrm{ml})$ of the cochineal extract.

\begin{tabular}{|c|c|c|c|c|c|c|}
\hline \multirow{2}{*}{ Number } & \multicolumn{2}{|c|}{ Cochineal at $\mathrm{pH} 12$} & \multicolumn{2}{|c|}{$\begin{array}{l}0.4 \mathrm{ml} \text { of the cochineal extract } \\
\text { in } 10 \mathrm{ml} \text { of } \mathrm{AgNO}_{3}\end{array}$} & \multicolumn{2}{|c|}{$\begin{array}{l}0.1 \mathrm{ml} \text { of the cochineal extract } \\
\text { in } 10 \mathrm{ml} \text { of } \mathrm{AgNO}_{3}\end{array}$} \\
\hline & Wavelength $(\mathrm{nm})$ & $\begin{array}{l}\text { Spectral width } \\
(\mathrm{HWHM})(\mathrm{nm})\end{array}$ & Wavelength (nm) & $\begin{array}{l}\text { Spectral width } \\
(\mathrm{HWHM})(\mathrm{nm})\end{array}$ & Wavelength (nm) & $\begin{array}{l}\text { Spectral width } \\
(\mathrm{HWHM})(\mathrm{nm})\end{array}$ \\
\hline 1 & 203.02 & 8.72 & 203.02 & 7.90 & 203.02 & 8.70 \\
\hline 2 & 273.58 & 14.69 & 279.30 & 16.70 & 280.00 & 22.00 \\
\hline 3 & 303.17 & 20.56 & 303.50 & 12.00 & - & - \\
\hline 4 & - & - & - & - & 379.00 & 44.5 \\
\hline 5 & - & - & 428.50 & 66.00 & 433.00 & 47.00 \\
\hline 6 & 489.59 & 22.20 & 489.00 & 15.00 & - & - \\
\hline 7 & 525.75 & 21.63 & 522.26 & 21.50 & 522.26 & 29.00 \\
\hline 8 & 569.58 & 27.10 & 561.00 & 19.80 & 564.00 & 23.00 \\
\hline
\end{tabular}

The wavelengths correspond to the formation of silver nanoparticles and of the natural pigment (cochineal) [21-23].

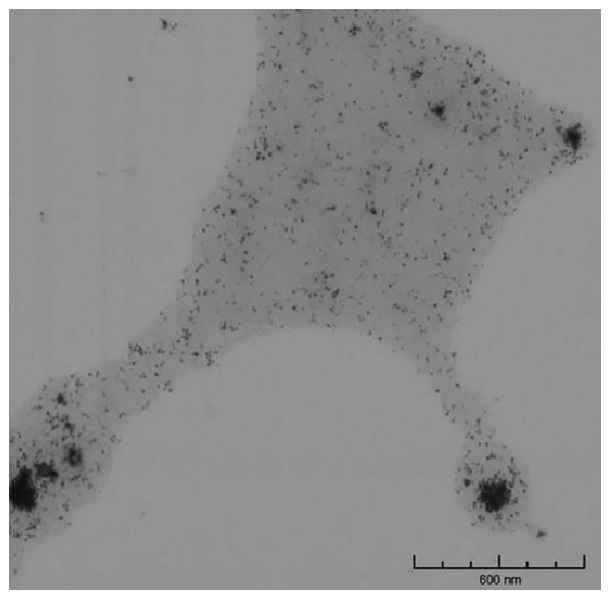

(a)

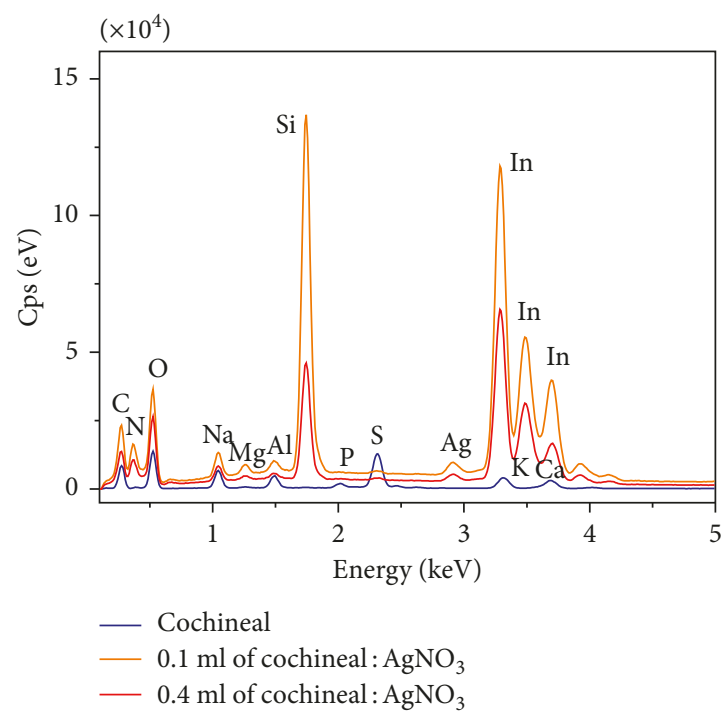

(c)

(c)

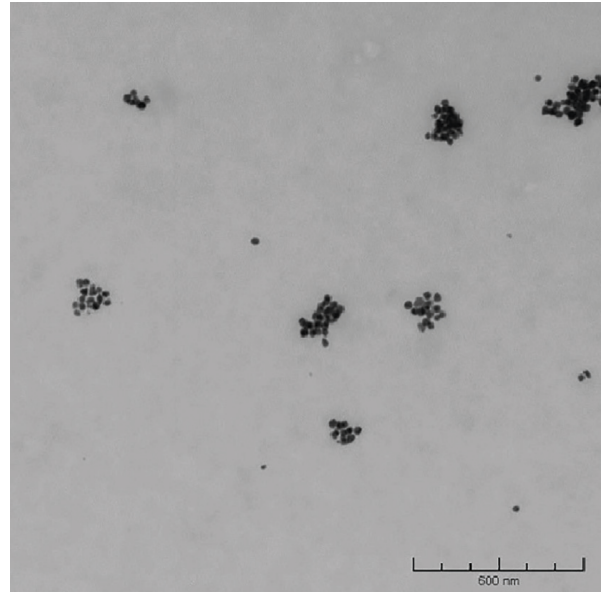

(b)

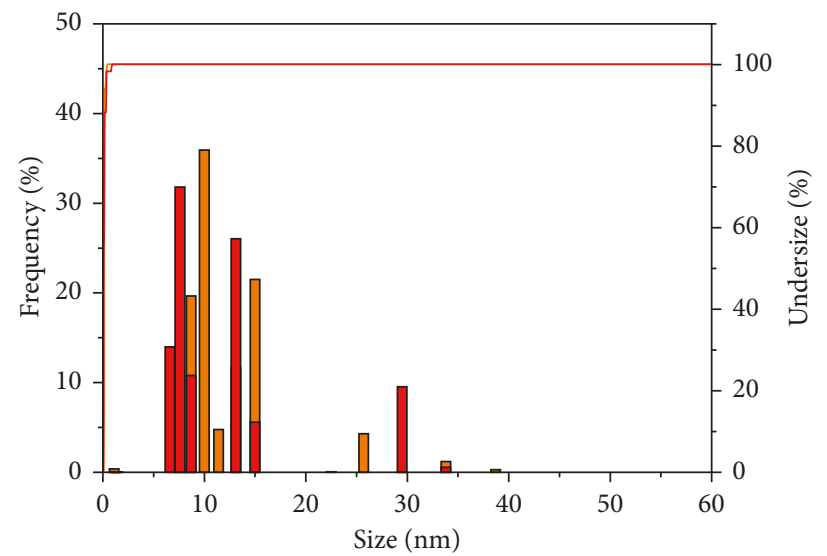

$0.1 \mathrm{ml}$ of cochineal : $\mathrm{AgNO}_{3}$ Mean: $11.4 \mathrm{~nm}$

Median: $9.7 \mathrm{~nm}$

SD: $4.4 \mathrm{~nm}$

$0.4 \mathrm{ml}$ of cochineal : $\mathrm{AgNO}_{3}$

Mean: $12 \mathrm{~nm}$

Median: $8 \mathrm{~nm}$

SD: $9.9 \mathrm{~nm}$

(d)

FIGURE 4: Scanning transmission electron micrographs of AgNPs synthesized from $0.1 \mathrm{ml}$ (a) and $0.4 \mathrm{ml}$ (b) of the cochineal extract and their (c) EDS spectra and (d) DLS analyses. 
TABLE 2: Major elemental composition (weight percent) of cochineal pigment and AgNPs synthesized from 0.1 and $0.4 \mathrm{ml}$ of the cochineal extract.

\begin{tabular}{|c|c|c|c|}
\hline \multirow{2}{*}{ Elements } & \multicolumn{3}{|c|}{ wt.\% } \\
\hline & Cochineal at $\mathrm{pH} 3.8$ & $0.1 \mathrm{ml}$ of the cochineal extract & $0.4 \mathrm{ml}$ of the cochineal extract \\
\hline $\mathrm{Ag}$ & - & $0.89 \pm 0.05$ & $0.83 \pm 0.02$ \\
\hline $\mathrm{Na}$ & $0.21 \pm 0.04$ & $1.29 \pm 0.11$ & $1.50 \pm 0.13$ \\
\hline $\mathrm{Mg}$ & $0.40 \pm 0.05$ & $0.37 \pm 0.04$ & $0.35 \pm 0.05$ \\
\hline $\mathrm{Al}$ & $0.42 \pm 0.03$ & $0.30 \pm 0.03$ & $0.31 \pm 0.04$ \\
\hline S & $6.18 \pm 0.25$ & - & $0.02 \pm 0.01$ \\
\hline
\end{tabular}

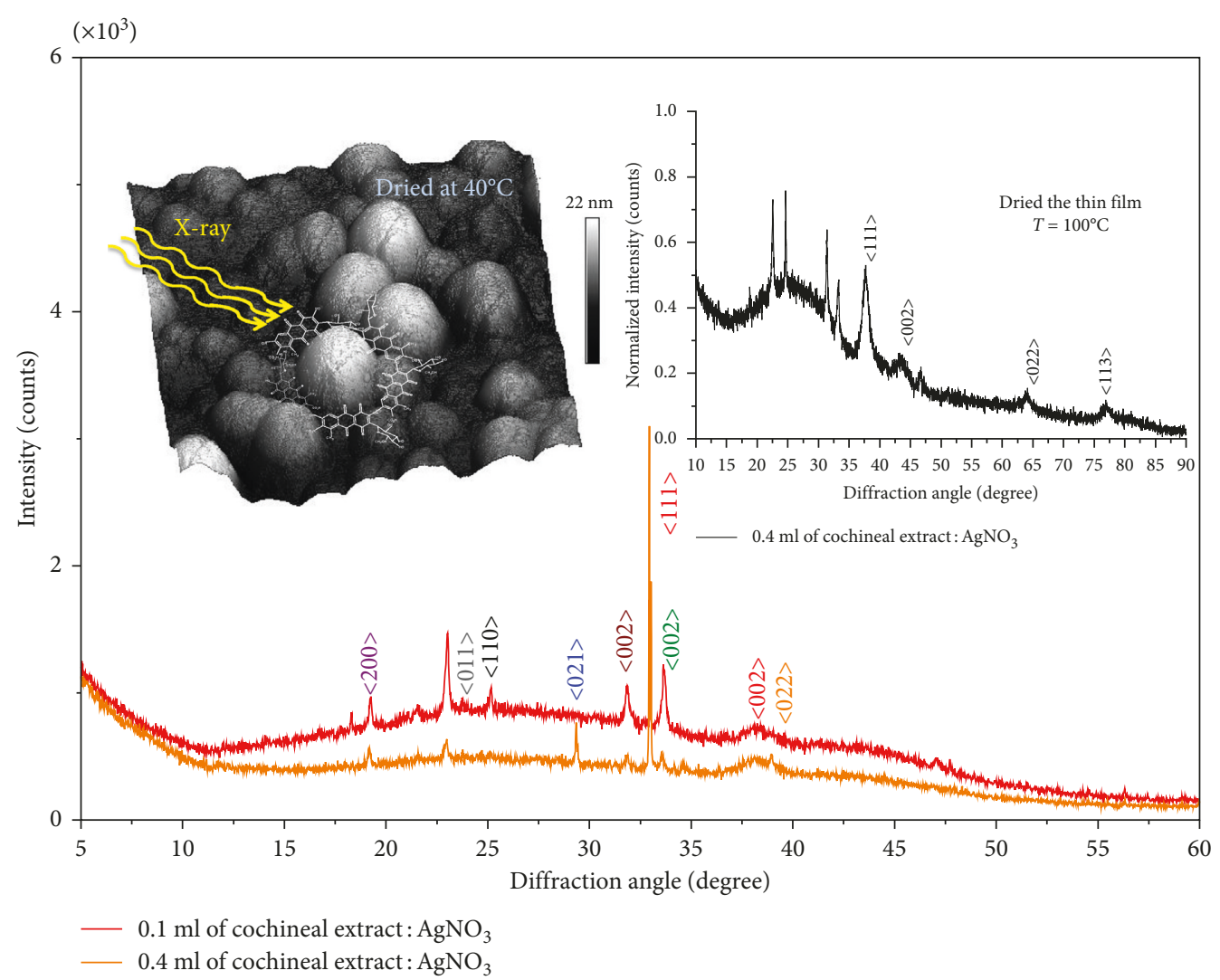

FIgURE 5: XRD patterns of AgNP thin films ( 0.1 and $0.4 \mathrm{ml}$ of cochineal extract solution) dried at $40^{\circ} \mathrm{C}$. Inset shows the schematic representation of X radiation in the thin film and the XRD pattern of AgNPs synthesized with $0.4 \mathrm{ml}$ of the cochineal extract (same batch) but dried at $100^{\circ} \mathrm{C}$ confirming the formation of face centre cubic silver.

TABLe 3: Crystal structure analysis of AgNPs synthesized from 0.1 and $0.4 \mathrm{ml}$ of the cochineal extract dried at 40 and $100^{\circ} \mathrm{C}$.

\begin{tabular}{|c|c|c|c|c|c|c|}
\hline \multirow[b]{2}{*}{ Name } & \multirow[b]{2}{*}{ Crystal system } & \multirow[b]{2}{*}{$<\mathrm{hkl}>$} & \multirow[b]{2}{*}{ Color } & \multicolumn{3}{|c|}{$\%$} \\
\hline & & & & \multicolumn{2}{|c|}{ Dried at $40^{\circ} \mathrm{C}$} & $\begin{array}{c}0.4 \mathrm{ml} \\
\text { Dried at } 100^{\circ} \mathrm{C}\end{array}$ \\
\hline Chlorargyrite & Cubic & $<002>$ & Green & 2.1 & 3.2 & \\
\hline Silver oxide & Cubic & $\begin{array}{l}<111> \\
<002>\end{array}$ & Red & 0.3 & 3.7 & \\
\hline Sodium sulfide & Cubic & $<022>$ & Orange & 14.6 & 12.2 & \\
\hline Sulfur helical & Hexagonal & $<110>$ & Black & 15.2 & 26.1 & \\
\hline Ice & Tetragonal & $<021>$ & Blue & 36.3 & 21.4 & \\
\hline Halite & Cubic & $<002>$ & Wine & 11.0 & 10.8 & \\
\hline Aluminium trihydroxide & Monoclinic & $<200>$ & Violet & 2.2 & 2.1 & \\
\hline Potassium & Cubic & $\begin{array}{l}<001> \\
<111>\end{array}$ & Plum & 2.1 & 2.5 & \\
\hline Silver & Cubic & $\begin{array}{l}<002> \\
<022> \\
<113>\end{array}$ & Black & - & - & 42.3 \\
\hline
\end{tabular}

Values are obtained by Rietveld analysis. 
organic matrix which surrounds the AgNPs produces increased scattering of X-rays, limiting observation of the silver crystals. When the thin film was dried at $100^{\circ} \mathrm{C}$, silver crystals were detected (Table 3) [25-28]. The clear detection of silver crystals was observed due to the degradation of organic compounds at that temperature. The relation detected by XRD for the two volumes of the cochineal extract of $0.4 \mathrm{ml}$ and $0.1 \mathrm{ml}$ for $\mathrm{AgCl}$ and $\mathrm{Ag}_{2} \mathrm{O}$ shows that the AgNPs formation was greater at the higher cochineal volume, which was confirmed by STEM micrographs, the physical-chemical analysis by EDS, and UV-Vis absorption spectroscopy.

3.3. Cyclic Voltammetry Characterization. Figure 6 shows the cyclic voltammogram of the cochineal pigment and of the two hybrid materials within a potential window of -1.0 to $1.2 \mathrm{~V}$. The cochineal extract exhibited no reduction peak; however, three oxidation peaks were observed at $-0.14,-0.32$, and $-0.61 \mathrm{~V}$ in the aqueous medium. Curves b $(0.1 \mathrm{ml}$ of the cochineal extract $)$ and $\mathrm{c}(0.4 \mathrm{ml}$ of the cochineal extract) exhibit the reduction of $\mathrm{AgNO}_{3}$ by oxidation of the cochineal pigment with concomitant formation of AgNPs. The two curves ( $b$ and $c$ ) exhibit the oxidation $(+0.88 \mathrm{~V})$ and reduction $(-0.18 \mathrm{~V})$ of the cochineal extract. $0.4 \mathrm{ml}$ of the cochineal extract sample (curve c) also shows a reduction event occurring at $-0.66 \mathrm{~V}$. Curves $\mathrm{b}(0.1 \mathrm{ml}$ of the cochineal extract $)$ and $c(0.4 \mathrm{ml}$ of the cochineal extract) exhibit the reduction of the $\mathrm{Ag}^{+}$ions to elemental $\mathrm{Ag}^{0}$ by cochineal oxidation leading to stable AgNPs; however, the two curves also show the contribution of $\mathrm{AgNO}_{3}$. Likewise, the oxidation of $\mathrm{Ag}^{+}$to $\mathrm{Ag}_{2} \mathrm{O}$ is observed, especially in $0.1 \mathrm{ml}$ of the cochineal extract sample in which the amount of reductant to $\mathrm{AgNO}_{3}$ ratio was smaller. These results show that a higher volume of cochineal is required to avoid the formation of $\mathrm{Ag}_{2} \mathrm{O}$ and ascertain the reduction of $\mathrm{AgNO}_{3}$ with reasonable reaction kinetics $[29,30]$.

The reduction of $\mathrm{AgNO}_{3}$ is probably due to electron transfer from carboxyl/hydroxyl groups of cochineal to $\mathrm{Ag}^{+}$ resulting in stable AgNPs. The energy gap and ionization potential of the biosynthesis of AgNPs from cochineal were estimated with optical and electrochemical techniques [31]. Based on these values, the highest occupied molecular orbital (HOMO) and lowest unoccupied molecular orbital (LUMO) energy levels could be determined (Table 4). These results show that the AgNPs synthesized from $0.4 \mathrm{ml}$ of the cochineal extract have a smaller energy gap and thus have better photon absorbance $(2.169 \mathrm{eV})$ than the corresponding AgNPs synthesized from $0.1 \mathrm{ml}$ of the cochineal extract $(2.669 \mathrm{eV})$ in the UV-Vis region.

3.4. AFM and Electrical Measurements. Figures 7(a)-7(d) show AFM images from the samples of the cochineal pigment and AgNPs ( $0.4 \mathrm{ml}$ and $0.1 \mathrm{ml}$ of the cochineal extract) on silicon. The roughness of the clusters was calculated to be $2.06 \pm 0.19 \mathrm{~nm}$ (Figure $7(\mathrm{a})$, cochineal pigment), $5.94 \pm$ $1.30 \mathrm{~nm}$ (Figure 7(b), $0.4 \mathrm{ml}$ of the cochineal extract sample), and $2.96 \pm 0.35 \mathrm{~nm}$ (Figure $7(\mathrm{c}), 0.1 \mathrm{ml}$ of the cochineal extract sample). Figure $7(\mathrm{~d})$ shows an enlargement of the AFM image of AgNPs synthesized from $0.4 \mathrm{ml}$ of the

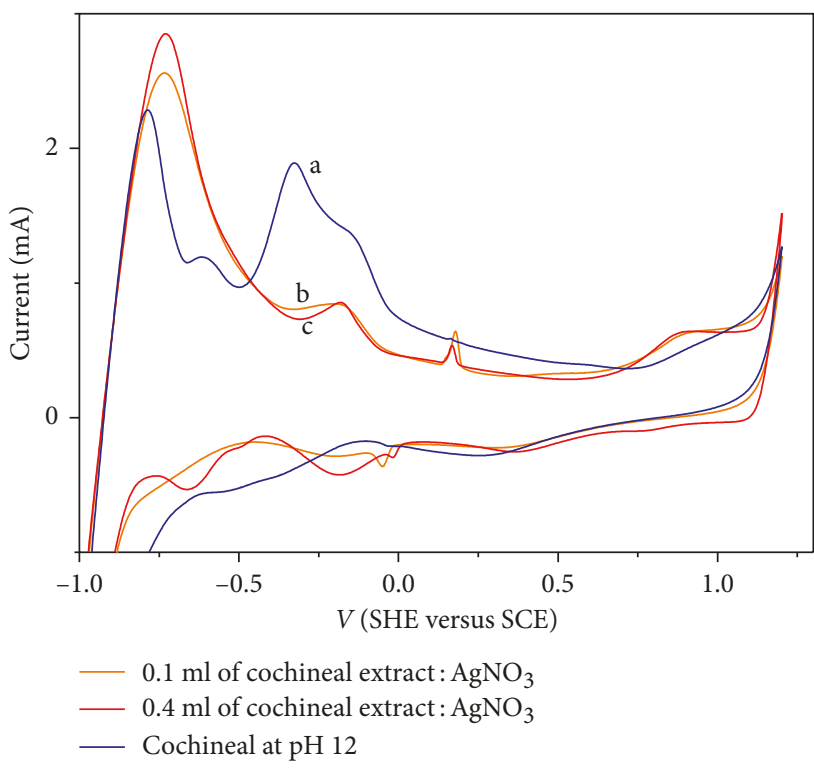

FIgURE 6: Cyclic voltammogram of cochineal pigment and AgNPs synthesized from 0.1 and $0.4 \mathrm{ml}$ of the cochineal extract. $\mathrm{SHE}=$ saturated hydrogen electrode; SCE = saturated calomel electrode.

TABLE 4: Energy levels of cochineal pigment ( $\mathrm{pH}$ 12.0) and AgNPs (0.1 and $0.4 \mathrm{ml}$ of the cochineal extract).

\begin{tabular}{lccc}
\hline Energy & $\begin{array}{c}0.4 \mathrm{ml} \text { of the } \\
\text { at pH } 12\end{array}$ & $\begin{array}{c}0.1 \mathrm{ml} \text { of the } \\
\text { in } 10 \mathrm{ml} \text { of } \\
\mathrm{AgNO}_{3}\end{array}$ & $\begin{array}{c}\text { in } 10 \mathrm{ml} \text { of } \\
\mathrm{AgNO}_{3}\end{array}$ \\
\hline HOMO $(\mathrm{eV})$ & $\begin{array}{c}-5.178 \pm \\
0.001\end{array}$ & $-5.074 \pm 0.002$ & $-5.049 \pm 0.004$ \\
& $-3.055 \pm$ & $-2.905 \pm 0.003$ & $-2.380 \pm 0.002$ \\
\hline
\end{tabular}

cochineal extract on a silicon substrate. The differences between the nanoparticles from the two ((Figure 7(b), $0.1 \mathrm{ml}$ of the cochineal extract) and (Figure $7(\mathrm{c}), 0.4 \mathrm{ml}$ of the cochineal extract)) are clearly observed by the surface roughness being less in the case of AgNPs with $0.1 \mathrm{ml}$ of the cochineal extract compared to $0.4 \mathrm{ml}$ of the cochineal extract, which might contribute to the size increase of the AgNPs due to cochineal adsorption. Studies show that, to obtain a good efficiency of a hybrid device, it must have roughness around $2 \mathrm{~nm}$ [32]. In this case, the $0.4 \mathrm{ml}$ sample of the cochineal extract that exceeds this value due to the size of the AgNPs must undergo an optimization of the spincoating technique. This finding is in agreement with the size distributions shown in Figure 4(d). The effect of the potential size regulation is demonstrated in Figure 7 (e) for thin films of the cochineal pigment and AgNPs $(0.4$ and $0.1 \mathrm{ml}$ of the cochineal extract). The potential offset is positive indicating the level of conductivity possible for each sample for application in organic devices.

\section{Conclusion}

This work demonstrates that, despite maintaining reaction time, temperature, and silver nitrate concentration, a change 


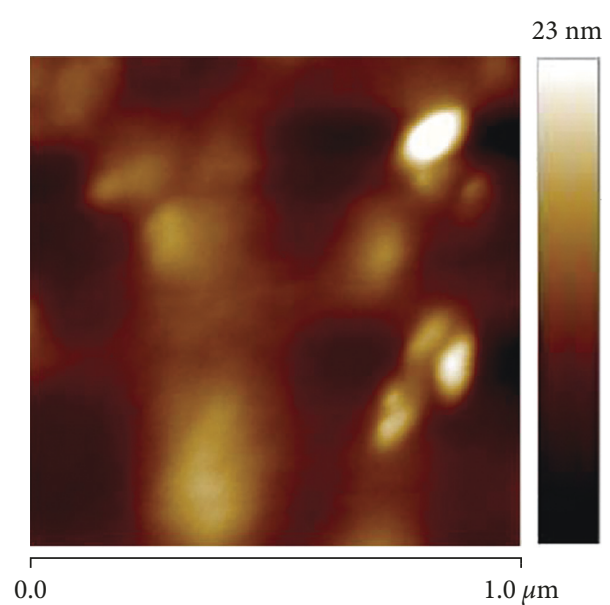

(a)

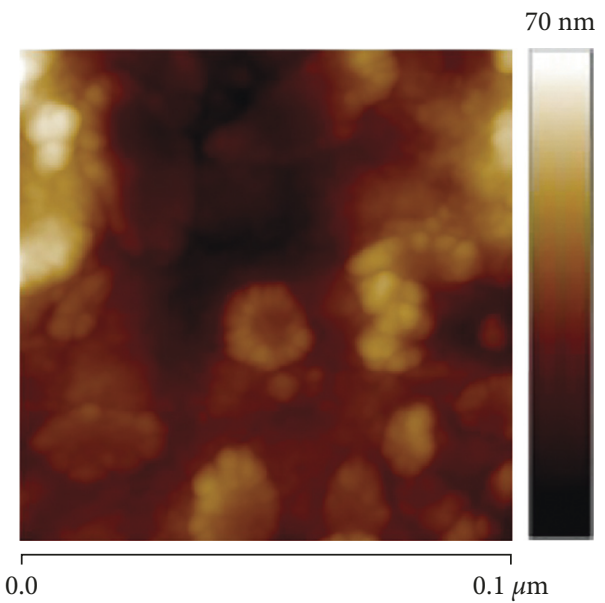

(c)

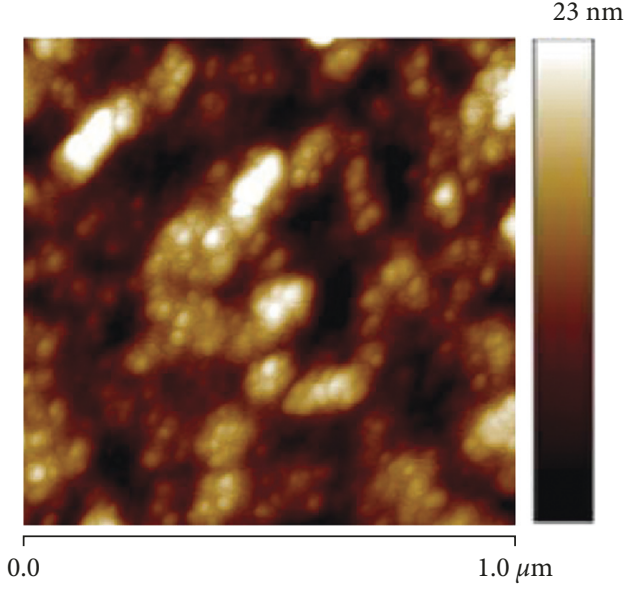

(b)

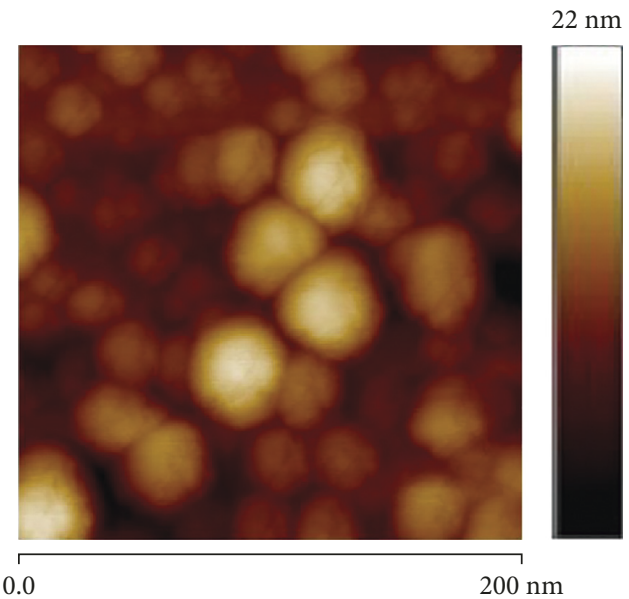

(d)

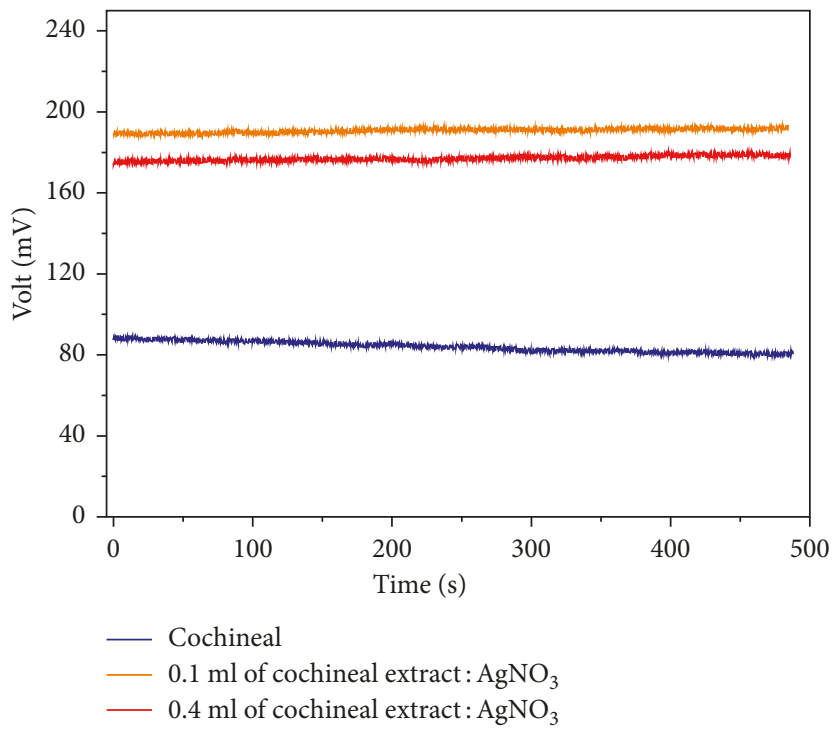

(e)

FIgURE 7: Atomic force micrographs of $1 \times 1 \mu \mathrm{m}^{2}$ thin films (on glass) of (a) cochineal pigment and AgNPs synthesized with (b) $0.1 \mathrm{ml}$ and (c) $0.4 \mathrm{ml}$ of cochineal extract solution. (d) Atomic force micrograph of $200 \times 200 \mathrm{~nm}^{2}$ from the same batch as shown in (c). Electric potential curves (e) as a function of time of cochineal pigment and AgNPs (0.1 and $0.4 \mathrm{ml}$ of the cochineal extract). 
of the LSPR band of AgNPs was observed as a function of the amount of cochineal applied. The higher cochineal concentration $(0.4 \mathrm{ml}$ of the cochineal extract) generated spherical AgNPs of 5 to $10 \mathrm{~nm}$ and good stability at room temperature. The trace of $\mathrm{Ag}_{2} \mathrm{O}$ observed in the sample (electrochemistry and XRD) probably stems from the concentration of cochineal used in the preparation process. If a slightly lowered concentration was used, incomplete reduction of silver nitrate is likely. Coating AgNPs with the cochineal pigment through direct biosynthesis improved the absorption spectrum in the $\mathrm{UV}-\mathrm{V}$ is range of the nanoparticles. The AgNPs in turn improve the electrical properties of the cochineal pigment converting it into a promising photoactive layer of organic solar cells.

\section{Conflicts of Interest}

The authors declare that they have no conflicts of interest.

\section{Acknowledgments}

This work was supported by a research grant (Grant no. 2014-PIT-034) of Universidad de las Fuerzas Armadas ESPE.

\section{Supplementary Materials}

Graphical abstract is included in this manuscript as a supplementary file. (Supplementary Materials)

\section{References}

[1] G. Krucaite, L. Liu, D. Tavgeniene et al., "Electroactive polymers containing 3-arylcarbazolyl units as hole transporting materials for OLEDs," Optical Materials, vol. 42, pp. 94-98, 2015.

[2] H. Duan, J. Yang, L. Fu et al., "Interface modification of organic photovoltaics by combining molybdenum oxide (MoOx) and molecular template layer," Thin Solid Films, vol. 574, pp. 146-151, 2015.

[3] C. Chappaz-Gillot, S. Berson, R. Salazar et al., "Polymer solar cells with electrodeposited CuSC nanowires as new efficient hole transporting layer," Solar Energy Materials and Solar Cells, vol. 120, pp. 163-167, 2014.

[4] G. Lopinski, N. Du, G. Dubey et al., "Cyanoethylated pullulan as a high-k solution processable polymer gate dielectric for SWCNT TFTs," Organic Electronics, vol. 42, pp. 329-336, 2017.

[5] B. Kumar, K. Smita, Y. Angulo, and L. Cumbal, "Green synthesis of silver nanoparticles using natural dyes of cochineal," Journal of Cluster Science, vol. 27, no. 2, pp. 703-713, 2016.

[6] M. Schoeser and J. Macdonald, Silk, Yale University Press, New Haven, CT, USA, 2007.

[7] M. González, M. Gloria Lobo, J. Méndez, and A. Carnero, "Food control, detection of colour adulteration in cochineals by spectrophotometric determination of yellow and red pigment groups," Food Control, vol. 16, no. 2, pp. 105-112, 2005.

[8] M. Shahid, S.-U. Islam, and F. Mohammad, "Recent advancements in natural dye applications: a review," Journal of Cleaner Production, vol. 53, pp. 310-331, 2013.

[9] B. Kumar, Y. Angulo, K. Smita, L. Cumbal, and A. Debut, "Capuli cherry-mediated green synthesis of silver nanoparticles under white solar and blue LED light," Particuology, vol. 24, pp. 123-128, 2016.
[10] B. Kumar, K. Smita, L. Cumbal, and A. Debut, "Ficus carica (fig) fruit mediated green synthesis of silver nanoparticles and its antioxidant activity: a comparison of thermal and ultrasonication approach," BioNanoScience, vol. 6, no. 1, pp. 15-21, 2016.

[11] B. Kumar, K. Smita, L. Cumbal, A. Debut, and R. N. Pathak, "Ionic liquid based silica tuned silver nanoparticles: novel approach for fabrication," Synthesis and Reactivity in Inorganic, Metal-Organic, and Nano-Metal Chemistry, vol. 46, no. 8, pp. 1265-1271, 2016.

[12] K. S. Vizuete, B. Kumar, K. Guzmán, A. Debut, and L. Cumbal, "Shora (Capparis petiolaris) fruit mediated green synthesis and application of silver nanoparticles," Green Processing and Synthesis, vol. 6, no. 1, pp. 23-30, 2017.

[13] M. E. Borges, R. L. Tejera, L. Díaz, P. Esparza, and E. Ibáñez, "Natural dyes extraction from cochineal (Dactylopius coccus). New extraction methods," Food Chemistry, vol. 132, no. 4, pp. 1855-1860, 2012.

[14] E. A. González, E. M. García, and M. A. Nazareno, "Free radical scavenging capacity and antioxidant activity of cochineal (Dactylopius coccus C.) extracts," Food Chemistry, vol. 119, no. 1, pp. 358-362, 2010.

[15] K. Do, C. Kim, K. Song, S. J. Yun, J. K. Lee, and J. Ko, “Efficient planar organic semiconductors containing fused triphenylamine for solution processed small molecule organic solar cells," Solar Energy Materials and Solar Cells, vol. 115, pp. 52-57, 2013.

[16] V. Shanmugam, S. Manoharan, S. Anandan, and R. Murugan, "Performance of dye-sensitized solar cells fabricated with extracts from fruits of ivy gourd and flowers of red frangipani as sensitizers," Spectrochemical Acta Part A: Molecular and Biomolecular Spectroscopy, vol. 104, pp. 35-40, 2013.

[17] M. R. Narayan, "Review: dye sensitized solar cells based on natural photosensitizers," Renewable and Sustainable Energy Reviews, vol. 16, pp. 208-215, 2012.

[18] T. Huang and X.-H. N. Xu, "Synthesis and characterization of tunable rainbow colored colloidal silver nanoparticles using single-nanoparticle plasmonic microscopy and spectroscopy," Journal of Materials Chemistry, vol. 20, no. 44, pp. 9867-9876, 2010.

[19] V. Dal Lago, L. F. de Oliveira, K. D. A. Goncalves, J. Kobarg, and M. B. Cardoso, "Size-selective silver nanoparticles: future of biomedical devices with enhanced bactericidal properties," Journal of Materials Chemistry, vol. 21, no. 33, pp. 1226712273, 2011.

[20] B. Chudasama, A. K. Vala, N. Andhariya, R. V. Mehta, and R. V. Upadhyay, "Highly bacterial resistant silver nanoparticles: synthesis and antibacterial activities," Journal of Nanoparticle Research, vol. 12, no. 5, pp. 1677-1685, 2010.

[21] J. F. Affonso de Oliveira and M. B. Cardoso, "Partial aggregation of silver nanoparticles induced by capping and reducing agents competition," Langmuir, vol. 30, no. 17, pp. 4879-4886, 2014.

[22] G. Favaro, C. Miliani, A. Romani, and M. Vagnini, "Role of protolytic interactions in photo-aging processes of carminic acid and carminic lake in solution and painted layers," Journal of the Chemical Society, Perkin Transactions, vol. 2, no. 1, pp. 192-197, 2002.

[23] E. H. Anouar, C. P. Osman, J.-F. F. Weber, and N. H. Ismail, "UV/Visible spectra of a series of natural and synthesised anthraquinones: experimental and quantum chemical approaches," SpringerPlus, vol. 3, p. 233, 2014. 
[24] D. de Marcano and M. Hasegawa, Fitoquímica Brgánica, Editorial Consejo de Desarrollo Científico y Humanístico, Venezuela, 1st edition, 1991.

[25] M. Šuleková, A. Hudák, and M. Smrcová, "The determination of food dyes in vitamins by RP-HPLC," Molecules, vol. 21, no. 10, p. 1368, 2016.

[26] P. Magudapathy, P. Gangopadhyay, B. K. Panigrahi, K. G. M. Nair, and S. Dhara, "Electrical transport studies of Ag nanoclusters embedded in glass matrix," Physica B: Condensed Matter, vol. 299, no. 1-2, pp. 142-146, 2001.

[27] S. Talekar, A. Joshi, R. Chougle, A. Nakhe, and R. Bhojwani, "Immobilized enzyme mediated synthesis of silver nanoparticles using cross-linked enzyme aggregates (CLEAs) of NADH-dependent nitrate reductase," Nano-Structures and Nano-Objects, vol. 6, pp. 23-33, 2016.

[28] D. K. Lee and Y. S. Kang, "Synthesis of silver nanocrystallites by a new thermal decomposition method and their characterization," ETRI Journal, vol. 26, no. 3, pp. 252-256, 2004.

[29] J. Tian, S. Liu, Y. Zhang et al., "Environmentally friendly, onepot synthesis of Ag nanoparticle-decorated reduced graphene oxide composites and their application to photocurrent generation," Inorganic Chemistry, vol. 51, no. 8, pp. 47424746, 2012.

[30] R. M. Thangavelu, D. Gunasekaran, M. I. Jesse, S. U. Mohammed Riyaz, D. Sundarajan, and K. Krishnan, "Nanobiotechnology approach using plant rooting hormone synthesized silver nanoparticle as "nanobullets" for the dynamic applications in horticulture-an in vitro and ex vitro study," Arabian Journal of Chemistry, vol. 11, no. 1, pp. 48-61, 2016.

[31] W.G. Quirino, C. Legnani, R. M. B. dos Santos et al., "Electroluminescent devices based on rare-earth tetrakis $\beta$-diketonate complexes," Thin Solid Films, vol. 517, no. 3, pp. 1096-1100, 2008.

[32] C.-C. Chen, S. H. Chang, L.-C. Chen et al., "Improving the efficiency of inverted mixed-organic-cation perovskite absorber based photovoltaics by tailing the surface roughness of PEDOT: PSS thin film," Solar Energy, vol. 134, pp. 445-451, 2016. 


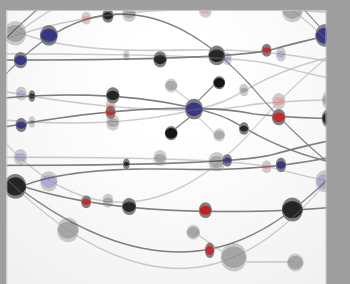

The Scientific World Journal
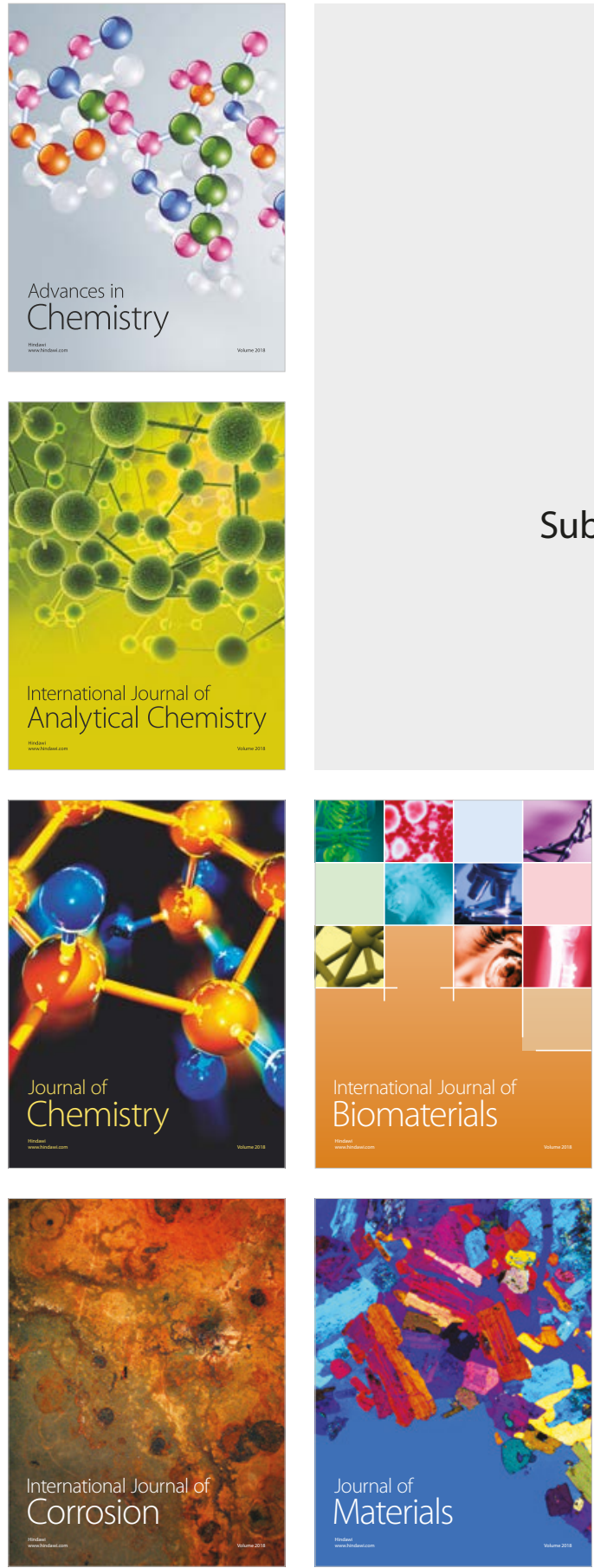

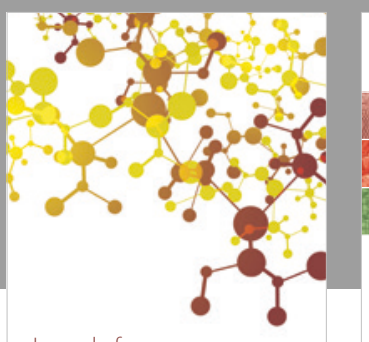

Journal of

Applied Chemistry
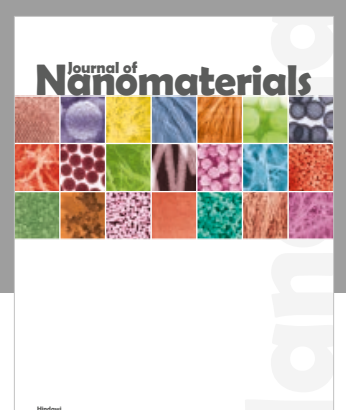

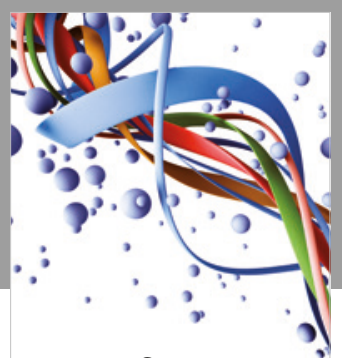

Scientifica

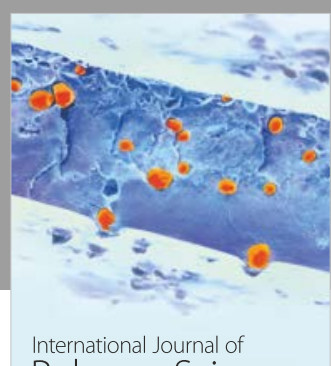

Polymer Science

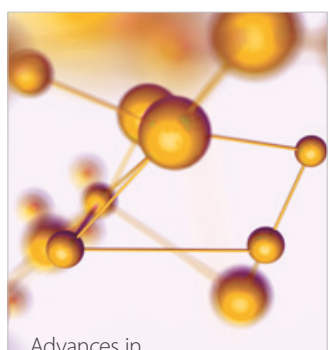

Physical Chemistry
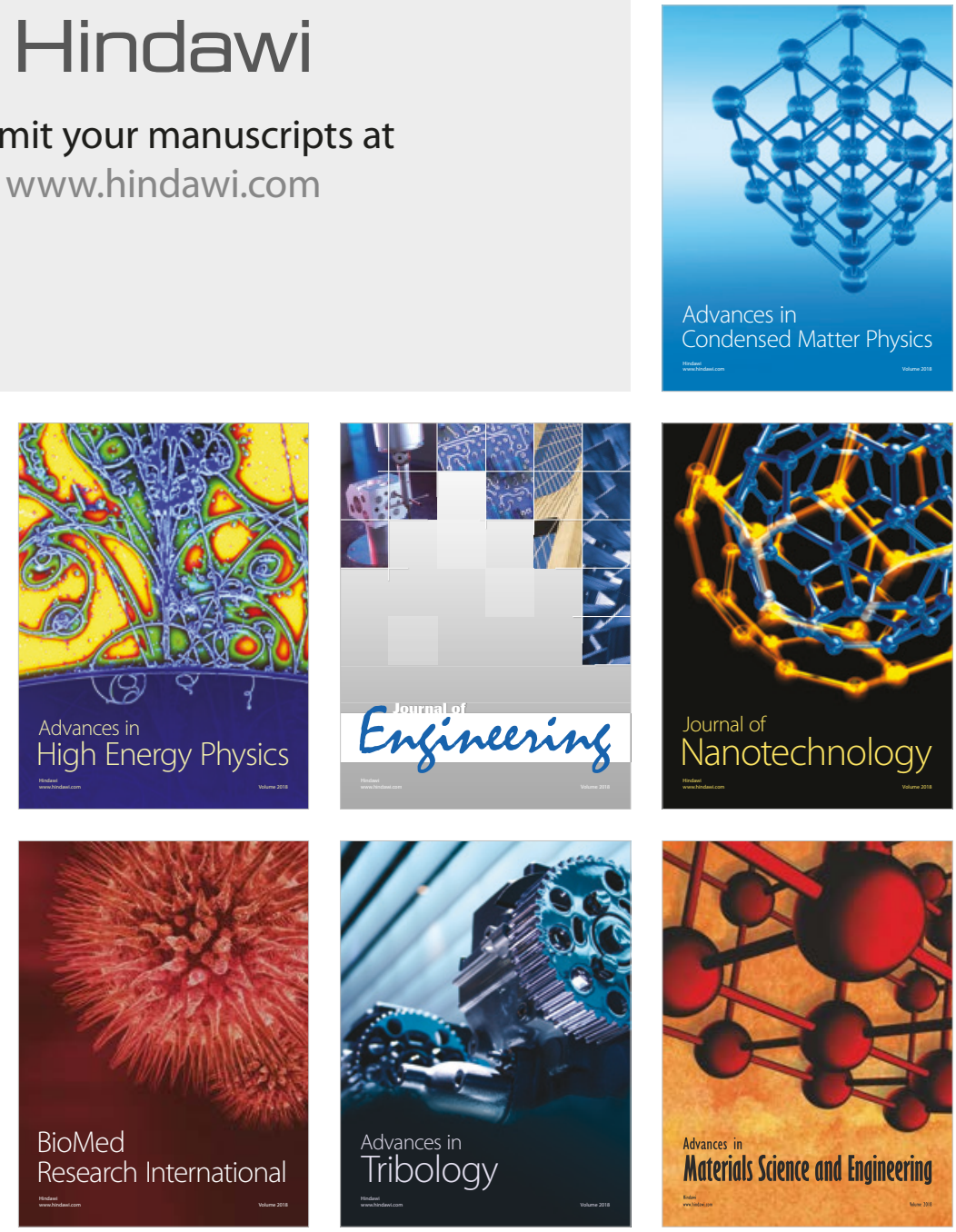